\title{
A NEW SPECIES OF Praemichelinia (TABULATA) FROM THE EMSIAN (LOWER DEVONIAN) OF COLLE (CANTABRIAN MOUNTAINS, NW SPAIN) AND THE OCCURRENCE OF SOLENIA-LIKE PORES IN THE GENUS
}

\author{
Esperanza FERNÁNDEZ-MARTÍNEZ1 and Yves \\ PLUSQUELLEC ${ }^{2}$
}

${ }^{1}$ Universidad de León. Departamento de Ingeniería Minera. c/ Jesús Rubio, 2. 24071 León. Spain. dimefm@unileon.es

${ }^{2}$ Université de Bretagne Occidentale. UMR 6538 Domaines océaniques, Laboratoire de Paléontologie. Faculté des Sciences. 6, Avenue Le Gorgeu -

C.S. 93837. 29238 Brest Cedex 3. Francia. Yves.Plusquellec@univ-brest.fr

Fernández-Martínez, E. \& Plusquellec, Y. 2006. A new species of Praemichelinia (Tabulata) from the Emsian (Lower Devonian) of Colle (Cantabrian Mountains, NW Spain) and the occurrence of solenia-like pores in the genus. [Una nueva especie de Praemichelinia (Tabulata) del Emsiense (Devónico Inferior) de Colle (Cordillera Cantábrica, NO de España) y la presencia de poros de tipo solenia en el género]. Revista Española de Paleontología, 21 (1), 43-59. ISSN 0213-6937.

\begin{abstract}
This paper comprises a detailed systematic study of material corresponding to Tabulate corals found in the Upper Emsian (Lower Devonian) strata of the locality of Colle, on the southern slope of the Cantabrian Mountains (NW Spain) which is assigned to a new species of the genus Praemichelinia. This species is characterized by the large size attained by its main corallites and by the occasional development of complete concave tabulae, disposed in series coexisting with incomplete tabulae and tabellae. In addition, solenia-like corner pores are reported in the genus for the first time. The description of this new species allows to reaffirm the validity of the genus Praemichelinia, as also its peri-Gondwanic distribution during the Lower Devonian.
\end{abstract}

Key words: Tabulata, Micheliniidae, Emsian, Cantabrian Mountains, Solenia, Microstructure, Palaeogeography

\section{RESUMEN}

En este trabajo se realiza un detallado estudio sistemático de material correspondiente a corales tabulados, procedente de estratos del Emsiense Superior (Devónico Inferior) de la localidad de Colle, en la vertiente sur de la Cordillera Cantábrica (NO de España), el cual se asigna a una nueva especie del género Praemichelinia. Esta especie se caracteriza por el gran tamaño alcanzado por sus coralitas principales, y por el desarrollo ocasional de tábulas cóncavas completas y dispuestas en series que coexisten con tábulas incompletas y con tabelas. Adicionalmente y por primera vez en este género, se señala la presencia de poros angulares de tipo solenia. La descripción de esta nueva especie permite reafirmar la validez del género Praemichelinia, y su distribución perigondwánica durante el Devónico Inferior.

Palabras clave: Tabulata, Micheliniidae, Emsiense, Cordillera Cantábrica, Solenia, Microestructura, Paleogeografia

\section{INTRODUCTION}

During a detailed palaeontological and stratigraphical study of the Colle site (Emsian, Cantabrian Mountains) carried out by Fernández et al. (in press) several specimens of micheliniid corals were found in a single bed, morphologically noteworthy for the large size of their corallites and showing clear signs of having been transported. This paper comprises a systematic study of this material. In these studied micheliniid corals solenia-like pores, neither 
hitherto recorded in the genus Praemichelinia nor in the family Micheliniidae, were recognized. Moreover, assignment of the material studied to a new species of the genus Praemichelinia (Lafuste \& Plusquellec, 1980) permits a new look to be taken at the palaeogeographical distribution of this genus during the Lower Devonian.

\section{GEOLOGICAL AND STRATIGRAPHICAL SETTING}

The studied samples were collected in the locality of Colle, from La Vid Group (Lochkovian-Emsian), a historical site located in the area within the Esla Unit, Fold and Nappe Region, on the southern slope of the Cantabrian Zone (Figs. 1,2). From a geographical point of view, this site is located in the northern part of the León Province (NW Spain).
The La Vid Group consists chiefly of limestones and dolostones, with an important shaley unit in its mid-upper part, termed the Valporquero Formation by Vilas Minondo(1971) and Vera de la Puente (1989) (Fig. 2). The upper part of this Valporquero Formation comprises a marly interval with bioclastic limestone intercalations and occasional development of biostromes and small mud mounds. Keller \& Gröstch (1990) designated this marly interval as the Sagüera Member of the Esla Formation. Samples were collected from a bioclastic limestone layer situated in this interval (Figs. 2, 3).

According to data on conodonts (García-López \& SanzLópez, 2002) and dacryoconarids (García-Alcalde, 1997) in both cases from samples collected at various points close to Colle, the Valporquero Formation is Upper Emsian in age (P. laticostatus to $P$. serotinus zones).

The micheliniid corals come from an interval characterized by the predominance of bioclastic packstones and

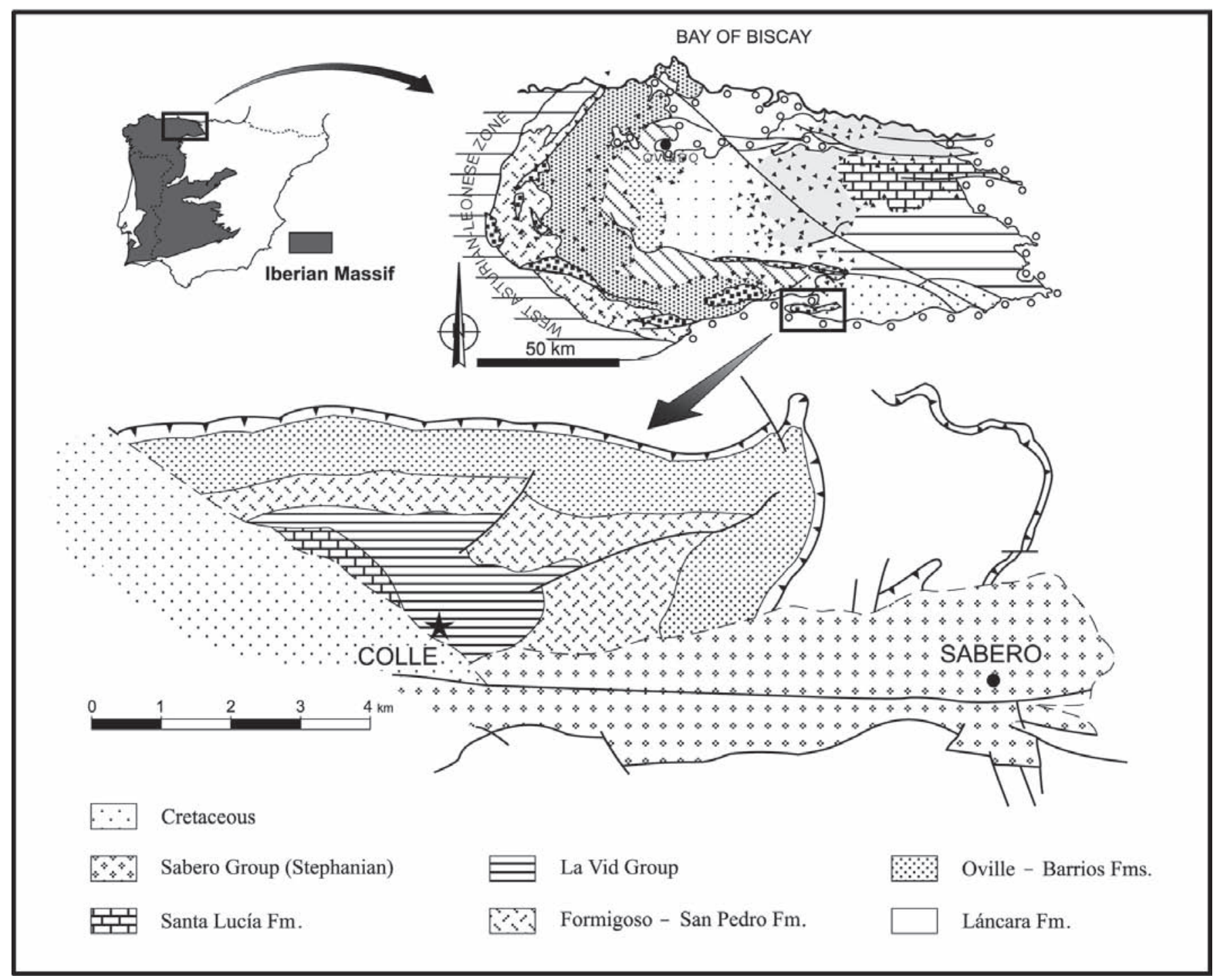

Figure 1. Schematic map of the Cantabrian Zone with the geological setting of the Colle outcrop, Felechas Syncline, Esla Unit, Fold and Nappe Region (after Alonso, 1989). The lithological symbols correspond only to the lower map. 

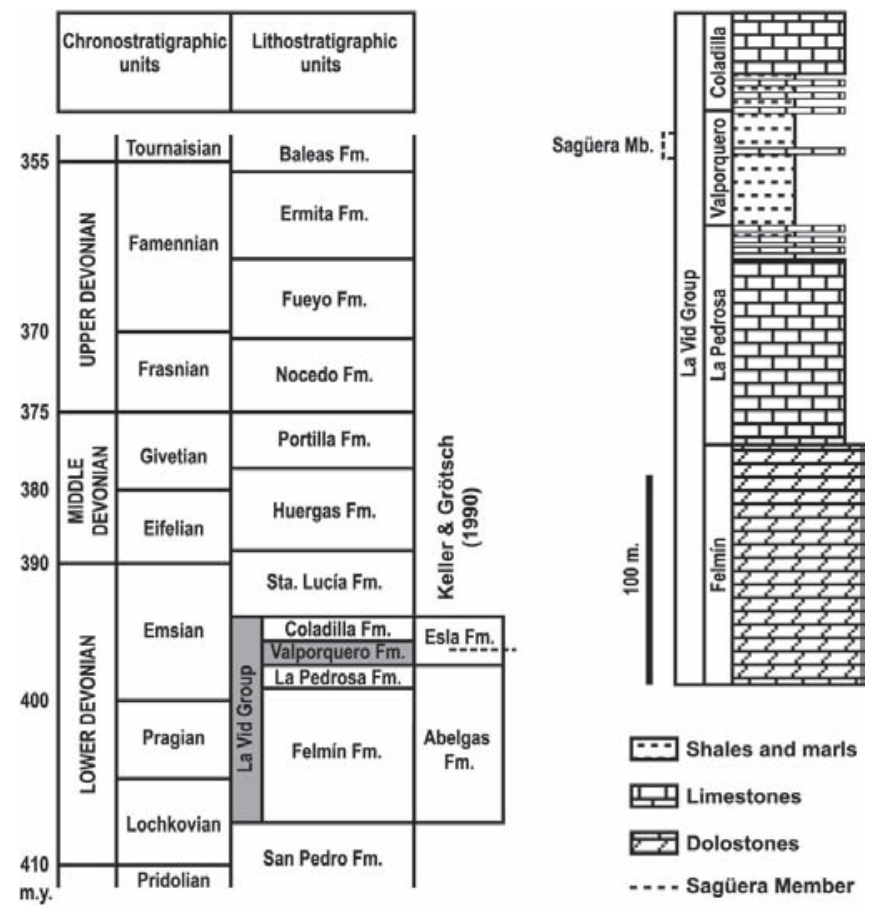

Figure 2. Chronological and stratigraphic chart showing the Devonian units of the Asturian-Leonian facies defined within the Province of Leon in the southern part of the Cantabrian Zone. Chart and absolute ages based on García-López \& Sanz-López (2002). To the right of this column details are given of these lithostratigraphic units, following the proposals of Keller \& Grötsch (1990), and the precise location of their Sagüera Member, where the studied samples were collected. The stratigraphic log on the right of the figure shows the general stratigraphy of the La Vid Group (after Vera de la Puente 1989).

grainstones with abundant rugose and tabulate corals, bryozoans and brachiopods. Floatstone and rudstone with large fragments of fasciculate rugose corals (Synaptophyllum Simpson, 1900) and micheliniid tabulate corals (Praemichelinia Lafuste \& Plusquellec, 1980) appear locally. The coralla studied in this paper were collected from one of these latter beds. Many of the bentic fossils, including the coralla of Praemichelinia, show borings and broken and oxidized margins. Macro and microfacies features suggest deposition by currents, which, at least in some cases, were produced by storms (Fernández et. al., in press).

\section{MATERIAL}

Three nearly complete coralla and four fragments of varying sizes from other colonies were collected. The more complete samples, designated DPO 15446, DPO 15447 and DPO 15448, were sectioned and studied by acetate peels, thin sections and ultrathin sections, as indicated below.

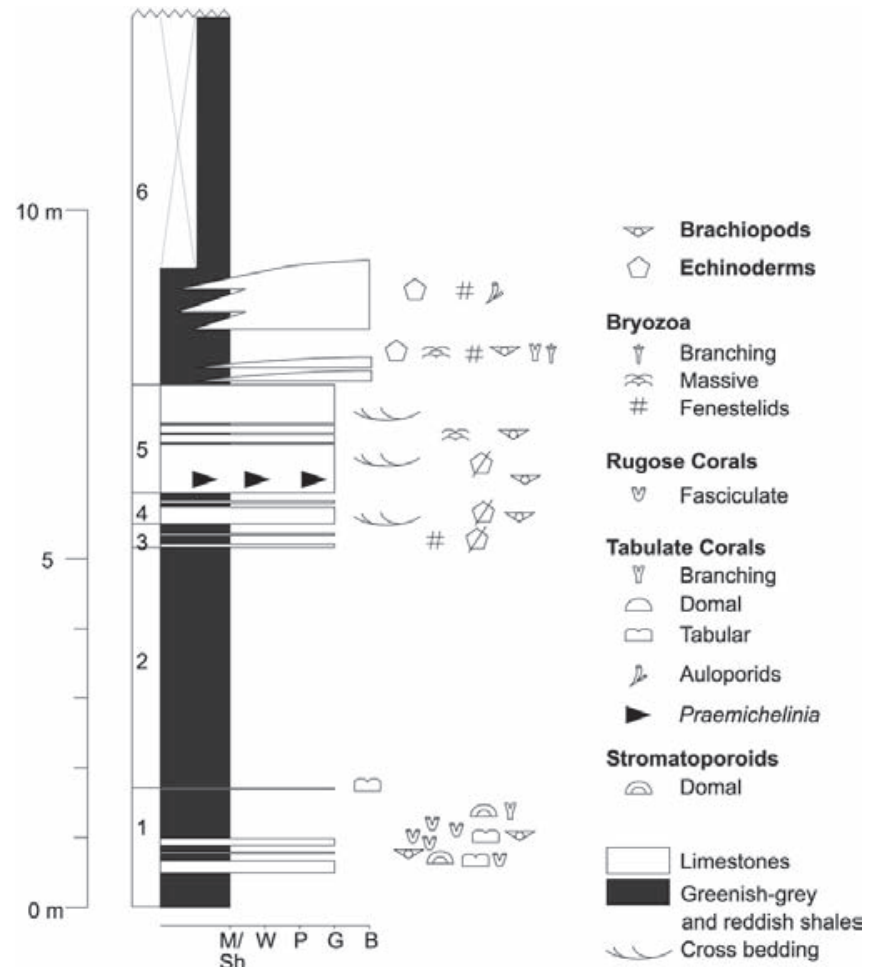

Figure 3. Stratigraphic column of the lower part of the Sagüera Member at Colle, just running along the hill where the local church stands. The precise bed where the studied samples were collected is indicated (simplified from unpublished work by L.P. Fernández).
Specimen DPO 15446: three thin sections (two cross-sections and one longitudinal section), and two acetate peels (transverse and longitudinal). Specimen DPO 15447: two thin sections (transverse and longitudinal) and two acetate peels (transverse and longitudinal). Specimen DPO 15448: three thin sections (transverse, tangential and longitudinal), four acetate peels (one crosswise, two crosswise-oblique and one longitudinal cut), and one ultrathin section (B 46840). In some cross-sections, the small size and the shape of the corallum generated an oblique cut of the outer corallites.

The specimens (fragments, acetate peels, thin and ultrathin sections) are housed at the Palaeontology Section of the Department of Geology of the University of Oviedo (Spain). Some duplicata of the acetate peels are housed in the Faculty of Sciences of the University of Brest: catalogue number LPB 14235.

\section{SYSTEMATICS}

Subclass TABULATA Milne-Edwards \& Haime, 1850

Order FAVOSITIDA Wedekind, 1937

Family Micheliniidae Waagen \& Wentzel, 1886 
Genus Praemichelinia Lafuste \& Plusquellec, 1980

Type species: Beaumontia? guerangeri Milne-Edwards \& Haime, 1851

Diagnosis (enmended): genus of Micheliniidae characterized by a wall composed of upwardly divergent lamellae. Septal spines ranging from well developed to absent. Tabulae complete or incomplete, somewhat vesicular. Face mural pores, corner pores and a few rare solenia-like pores. Corallum cerioid. Lateral increase. Epitheca possibly absent.

Discussion: Lafuste \& Plusquellec (1985) proposed a systematics for the family Micheliniidae, mainly based on microstructural features of the wall, which occupy a top-priority place in the hierarchy of systematic features. Thus, for the Devonian taxa, two lineages are recognized within this family: 1) taxa with lamellae set at an angle with a distal divergence, represented by the genera Praemichelinia and Saouraepora Plusquellec, Tourneur \& Lafuste, 1993, and 2) taxa with lamellae disposed in parallel with regard to the median dark line, represented by the genera Michelinia, Holacanthopora (probably synonymous with Michelinia) and Ohiopora.
On the other hand, the systematics adopted by Tchudinova (1997) put a certain number of genera defined by Lafuste \& Plusquellec (1985) as Praemichelinia, Ohiopora and Turnacipora, alongside classic genera such as Michelinia De Koninck, 1841, Rhizopora De Koninck, 1872 and Cystomichelinia Lin, 1962. This author does not take into account the precise microstructures either in herdiagnoses or in her generic discussions, nor does she point out the kind of pores present. Hence, the diagnosis of the genus Praemichelinia given by this author is as follows: «A massive coralla with large prismatic, polygonal corallites are distinctive for this genus. Walls of the corallites are thin in the axial zone and thickened at the corallum periphery. The microstructure of the walls is lamellar. Mural pores are abundant, irregularly disposed. Tabulae are complete, incomplete, convex and concave (as in the Favositida) at the early stages of astogeny. At the later stages, the walls of the corallites are thickened, tabulae are concave, convex, and vesicular (the latter are most strongly developed). Septa are well-developed in the form of trabecular spinules sometimes developed on the tabulae as well». Such a description can equally well be assigned to the genus Michelinia (Devonian-Carboniferous) and it is even valid for some taxa of Permian age.

Oekentorp \& Schröder (2001), who reject any systematic value for the microstructure, consider Praemichelinia synonymous with Protomichelinia Yabe \& Hayasaka, 1915. Independently of the value assigned to the microstructural
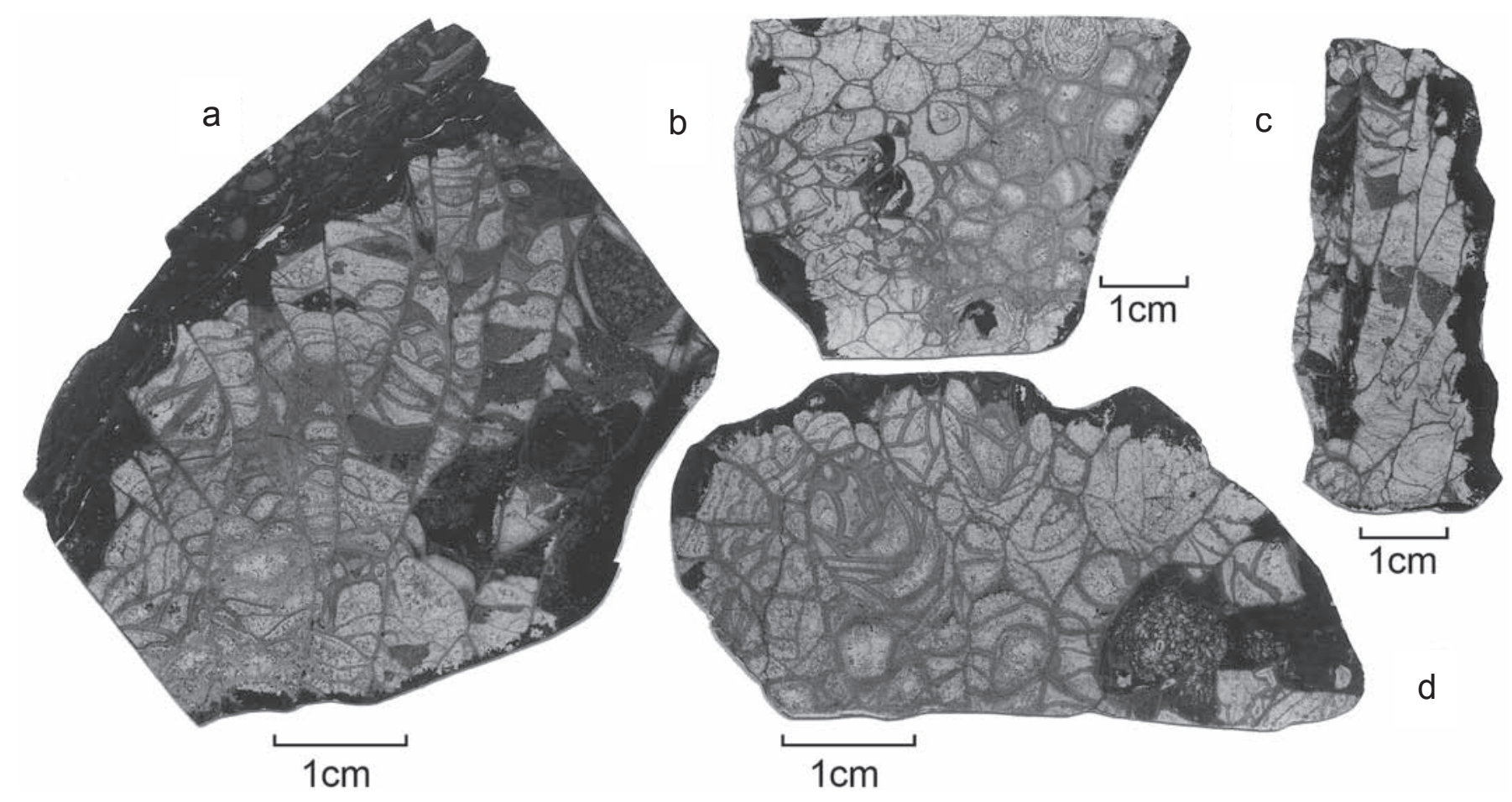

Figure 4. Praemichelinia steli n. sp. a: DPO 15447, paratype; longitudinal section showing the development of tabulae and tabellae, 1.5x. b: DPO 15448, paratype; thin section containing transverse and tangential sections of some main corallites, 1x. c: DPO 15448, paratype; longitudinal section displaying complete, concave tabulae, 1x. d: DPO 15448, paratype; longitudinal-oblique section showing the appearance of incomplete tabulae and tabellae, 1.5x. 
features, this proposal is not acceptable. For instance, the kind of tabulae developed in Praemichelinia is much closer to that in Michelinia s.s. than to the type present in certain particular Permian taxa, like Protomichelinia microstoma Yabe \& Hayasaka, 1915, the type species of the genus. This form is quite poorly known and according to these authors is characterized by «tabulae convex, very closely set and coalescing one with another».

In the absence of a convincing demonstration that the morphology, polarity and disposition of the lamellae (and microlamellae) in relation to the median dark line are no more than the result of diagenetic processes, it seems appropriate to accept the validity of the genus Praemichelinia, just as defined by Lafuste \& Plusquellec (1985). It is possible, as Nothdurft \& Webb (in press) propose, that the lamellae and microlamellae correspond to units that were originally fibrous and limited by a well differentiated organic sheath. Nevertheless, this fact would not rule out the systematic value of these elements, which would cease to be considered biocrystals and would become seen as units of a higher order, like the trabeculae.

The specimens from La Vid Group show all the features characteristic of this genus: cerioid corallum, tabulae complete, incomplete or vesicular; corner and face mural pores; walls with divergent lamellae and trabecular spines in the thickened peripheral regions.

Geographic and Stratigraphic Distribution: Ibarmaghian Domain: North Africa (Ougarta, Maïder), Spain (Iberian Chains, Ossa Morena Zone) and France (Armorican Massif). Malvinokaffric Domain: Bolivia. Lower-Upper Lochkovian to uppermost Emsian.

\section{Praemichelinia steli $\mathrm{n}$. sp.} Figs. 4-14

Derivatio Nominis: Dedicated to Jan H. Stel, the Dutch palaeontologist who studied the biostrome of the Colle outcrop from a palaeoecological and sedimentological point of view (Stel, 1976) and undertook an in-depth analysis of the significance of the solenia-like pores.

Material: Holotype DPO 15446 (Figs. 5a, 6c, 8, 9b, 11a, 12a-b) and 2 paratypes DPO 15447 (Figs. 4a, 5b-c, 6a, 9c, 10, 12c) and 15448 (Figs. 4b-d, 6b, 9a, 11b, 13a-b) from the locus typicus and stratum typicum.

Stratum typicum and locus typicus: Detrital packstone to grainstone with an intercalated local rudstone-floatstone bed (Fig. 3) including micheliniids and rugose corals. This series belongs to a shaley unit of the Valporquero Formation, La Vid Group, Upper Emsian. The marly interval is equivalent to the Saguiera member of the Esla Formation (Keller \& Gröstch, 1990) (Fig. 2). The section sampled is runs down the hill on which the church of Colle village stands (Fig. 1), ending just below this building, in the Esla Unit, Fold and Nappe Region, on the southern slope of the Cantabrian Mountains (NW Spain).
Diagnosis: Praemichelinia with an average diameter for the main corallites of 6 to $10 \mathrm{~mm}$. Wall thickness 0.12 to $0.3 \mathrm{~mm}$. Face mural pores, corner pores and sparse solenia-like pores. Pore diameter is between 0.15 and $0.25 \mathrm{~mm}$. Septal spines short, ranging from rare to absent. Tabulae complete, concave or convex. Sometimes a set of complete concave tabulae develops. Tabellae vertical to horizontal. Tabulae incomplete and tabellae with a vesicular appearance. Tabular and tabellar spacing mode is 1 to $2 \mathrm{~mm}$.

Description: The samples studied consist of a number of large bioclasts embedded in a calcareous matrix and so the outer wall of the coralla is usually broken, having oxidized margins (Fig. 4a). Coralla are cerioid and their precise morphology cannot be determined because of their inclusion in the rock, but they appear to have a globular growth form, with an approximate size range of $7 \mathrm{~cm}$ for both width and height. Longitudinal sections show corallites parallel in the lower and central parts of the corallum, diverging slightly in the outer regions (Figs. 4a, 5c). The holotype (DPO 15446) shows a small growth-interruption surface, followed by recovery and regeneration across the growth surface of the adjacent corallites (Fig. 6c). No evidence of epitheca or radiciform processes was noted.

The number of sides of the calices noted at the surface of the coralla is extremely variable, ranging from 3 sides in the smallest to 11 sides in the largest calices. The distal wall of these latter seems to be smooth. However, owing to the poor preservation of the coralla, it is not possible to rule out the presence of septal ridges of no great prominence. No mural pores were observed on these calicinal walls. The peripheral region of the calix consists of a number of deep convex surfaces, corresponding to the outer tabellae. The bottom of the calyx is usually deep and in some places shows various irregularities that reveal a tabellar origin.

The corallites composing the colonies are polygons of variable size (Figs. 4b, 5b, 6b). Corallite size was measured from median line to median line and in order to minimize the occasional bias due to the oblique angle of some sections a diameter at right angles to the maximum diameter was measured. In addition, corallite size was recorded in accordance with the maturity (or "age") of the corallites, which is given by the number of sides (Fig. 7a). The main corallites have 8 to 11 sides, and their diameter is commonly between 7 and $11 \mathrm{~mm}$. Sample DPO 15448 is slightly different, with many small corallites having 3 or 4 sides and with main corallites with as many as 15 , but smaller in size (6 to $10 \mathrm{~mm}$; see Fig. $7 \mathrm{a}$ ).

The double wall has a thickness commonly between 0.12 and $0.15 \mathrm{~mm}$, locally reaching 0.25 to $0.3 \mathrm{~mm}$.

Small septal spines, of which a number are usually sited on a single wall, occur locally (Fig. 6a, 8, 12). They consist of a single trabeculae, which are clearer than the wall into which they are inserted.

Pores are found both at the angle $\left(\mathrm{P}_{1}\right)$ and on the wall $\left(\mathrm{P}_{2}\right)$ (Figs. 8, 9) of corallites. Transverse sections show face mural pores of type $\mathrm{P}_{2}$ that are not located exclusively in the middle of a wall and two face mural pores often are present on one and the same wall (Fig. 9c). These observations suggest that face mural pores occur in at least two rows. Most of these pores have diameters in the range from 0.15 to $0.25 \mathrm{~mm}$ and both types occasionally have thin pore-plates (Fig. 9). 


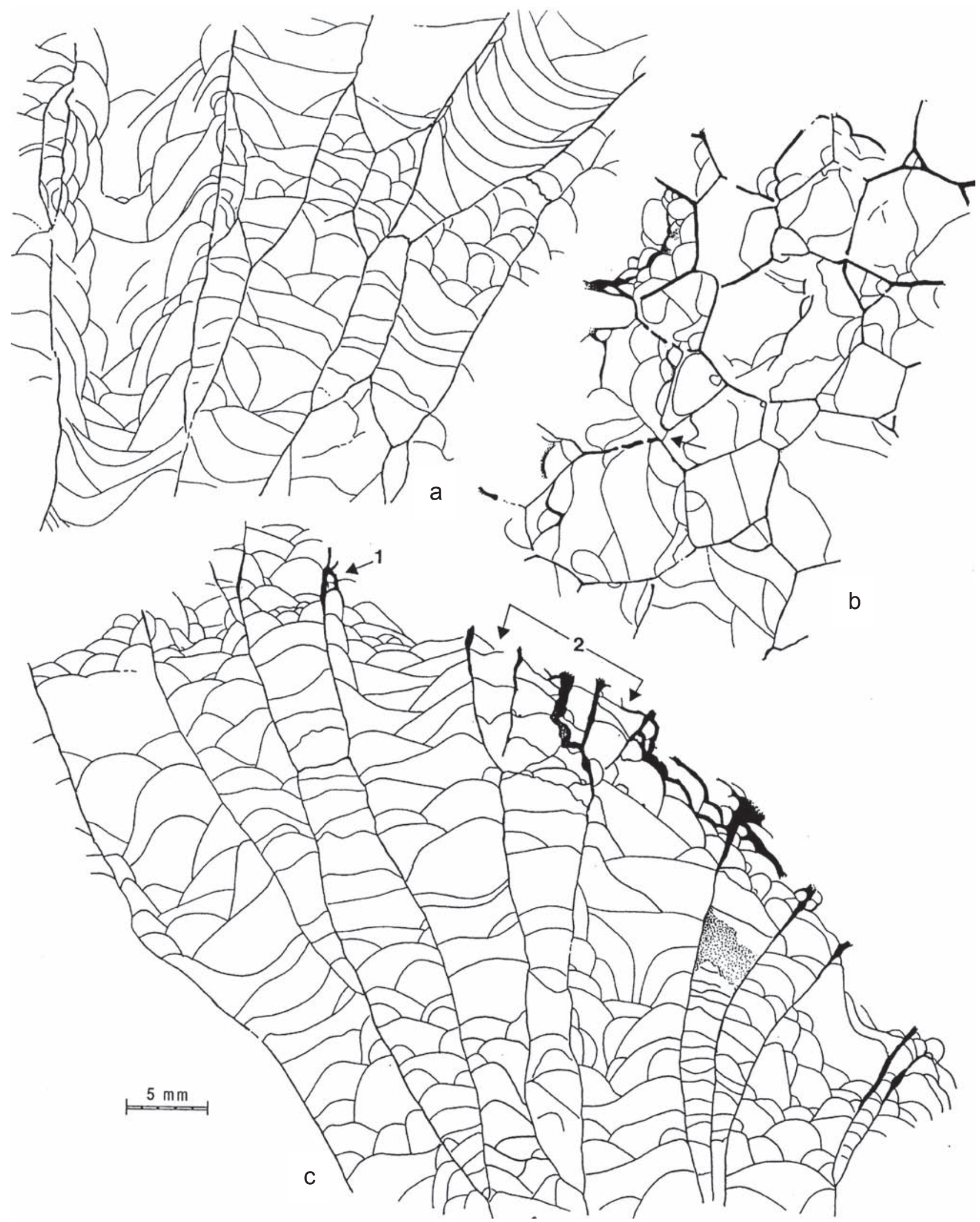

Figure 5. Praemichelinia steli n. sp. Skeletal structure, drawings from acetate peels. a: DPO 15446, holotype; longitudinal section showing major variations in the layout of tabulae and tabellae; of particular note is the corallite with a large set of concave, complete or slightly incomplete tabulae at the top right of the figure. b-c: DPO 15447, paratype; sections showing a slight thickening at the corallum periphery. $\mathbf{b}$ : Cross section (a more detailed view of the region indicated by the arrow may be seen in figure 9c). c: Longitudinal section (arrow 1 points to an area shown magnified in figure 12c, microstructure; arrow 2 indicates an area shown magnified in figure 10, budding). 

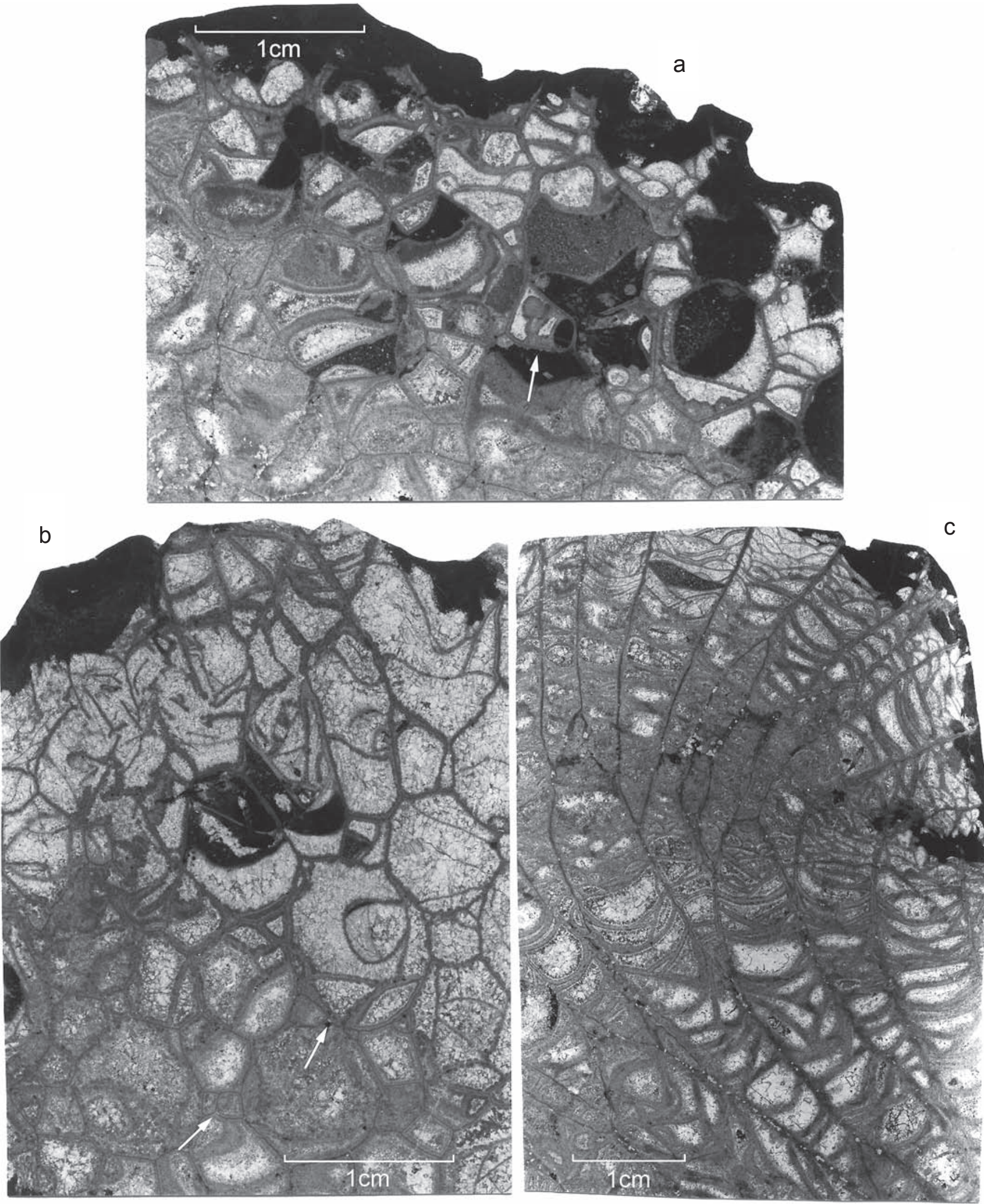

Figure 6. Praemichelinia steli $\mathrm{n}$. sp. a: DPO 15447, paratype; transverse and oblique sections of corallites; the arrow indicates a wall where small septal spines have developed locally in this specimen; the broken external zone of the coralla should be noted, 3x. b: DPO 15448, paratype; detail of Fig. 4b showing a main corallite surrounded by young corallites and the presence of two pores (arrows), 3x. c: DPO 15446, holotype; longitudinal section displaying the alternating development of regions where complete tabulae predominate and regions with incomplete tabulae and tabellae, $2 \mathrm{x}$. 
Besides the $\mathrm{P}_{1}$ and $\mathrm{P}_{2}$ types of pore, classically recognized in lamellar and microlamellar Micheliniidae, the samples from Colle have permitted the identification for the first time of the

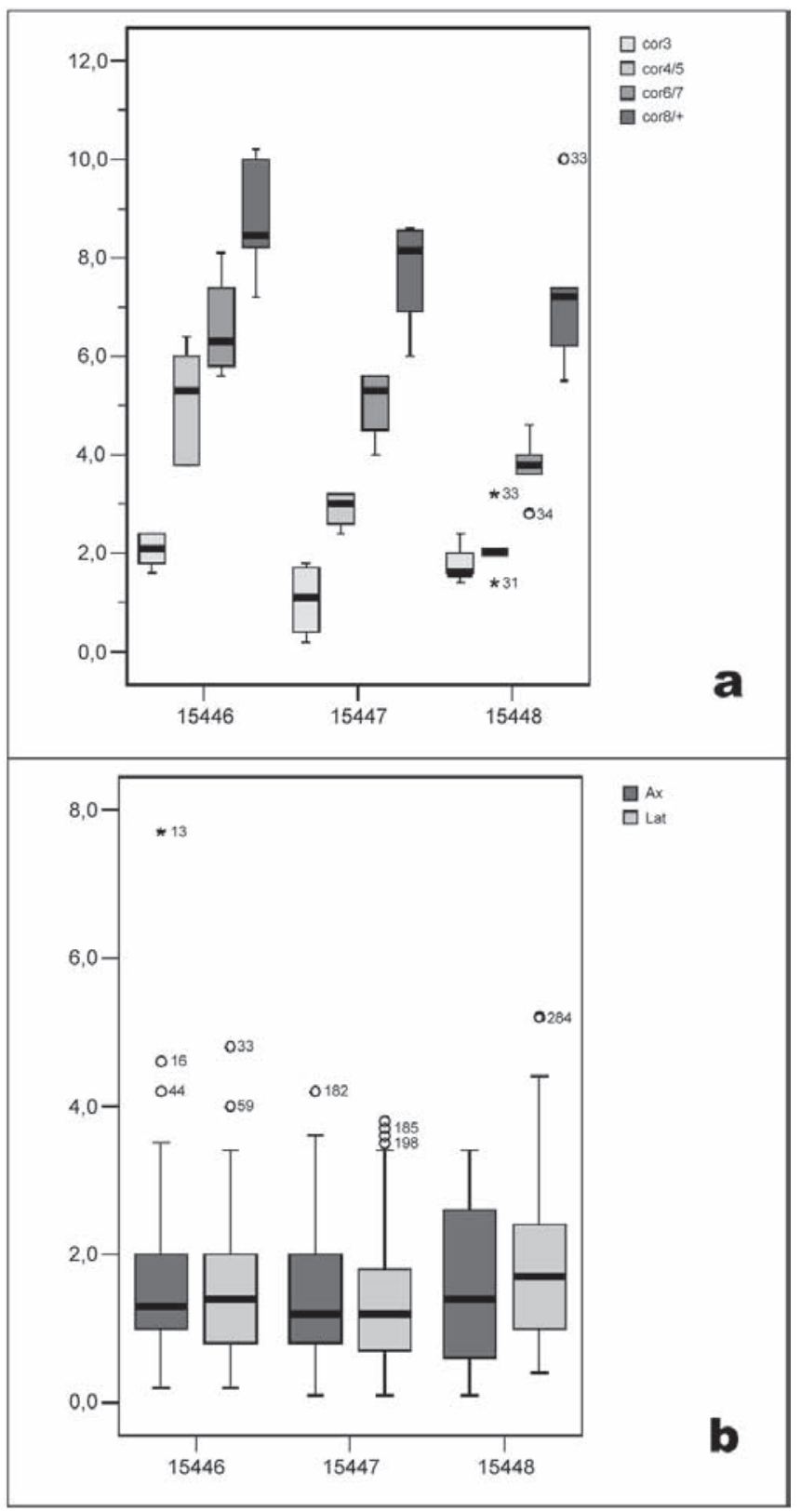

Figure 7. Praemichelinia steli n. sp. a. Box diagram plotting the diameter of corallites (in millimetres, on the vertical Y-axis) as a function of their number of sides (corallites with 3 sides, with 4 and 5 sides, with 6 and 7 sides, and with 8 or more sides being shown in different tones on the horizontal $\mathrm{X}$-axis) for each of the three samples. b. Box diagram representing the distance between consecutive tabulae and tabellae, measured at both the axial and the peripheral regions of the longitudinal sections of corallites. The box represents the inter-quartile range (IQR), the line in the box, the median. The lines outside the box (whiskers) are 1.5 times the IQR. Other symbols outside the box show outlier values. occurrence of a quite particular sort of pore, well known in Silurian Tabulata and especially in the genera Paleofavosites and Multisolenia. These are solenia-like pores (funnel-shaped pores) or "solenia-like corner pores", as Stel \& Oekentorp (1976) termed them. As these authors indicated, such pores seem to develop for preference between slender corallites and they are relatively rare in the material being reported here (Fig. 9).

In longitudinal sections two zones characterized by differing vertical developments were observed. The first stands out because of the presence of tabulae that are often complete, whereas the second is distinguished by the major occurrence of tabellae (Figs. $4 c, 5 a, 5 c$ and $6 c$, among others). A cyclomorphic origin has been suggested for these periodic morphological changes marked by the occurrence of different horizontal skeletal elements.

In the first of these regions complete tabulae are very frequent. They can be concave, convex, flat or undulating. They can also show various morphological irregularities (Figs. 4c and $6 \mathrm{c}$ particularly the lower part; see also Figs. 5a, c). In some places, a series of complete, usually concave, tabulae develops (Fig. 5a), though some convex tabulae and peripheral tabellae can also occur.

The development of tabellae with varied morphology and arrangement is typical of the second cyclomorphic region, where they can occupy the whole of the lumen (Figs. 4a, 6c, particularly the middle zone, just before the growth cessation, and the upper part of the figure; see also Figs. 5a, c). Sets of "sucker-like tabellae" distinguished by having both ends resting on the wall or on another similar tabellae and hence showing a vertical arrangement, are very common in the peripheral regions of the lumen. Some tabellae, with their internal ends resting on a tabula, also show a fairly marked inclination. In the central region of the larger corallites, tabellae usually show a more horizontal arrangement.

The distance between consecutive tabulae and tabellae was measured in both the axial and the peripheral regions of the corallites. Biometric data for this morphological feature (Fig. 7b) show that the mean distances between consecutive horizontal skeletal elements from marginal and axial regions are nearly the same. Furthermore, in the three specimens studied, the tabular spacing was mostly in the range from 1 to $2 \mathrm{~mm}$.

Locally, some thickened tabulae are observed, chiefly located in the peripheral zones of the coralla and always associated with regions where some tabellae occur (Figs. 4d, 6a, 8)

Corallite increase is lateral (peripheral) gemination. Longitudinal sections show some offsets connected to their parents by a basal pore (Fig. 10). A typical cella with re-entrant angles may be seen in transverse sections.

Microstructure: The wall consists of the usual two elements: a median dark line plus mural stereoplasm.

Thin sections $(30 \mu \mathrm{m})$ show a dark, narrow median dark line flanked on each side by a clear layer (Fig. 12) whose lamellar structure is confirmed by the study of ultrathin sections (called LFP section after Lafuste, 1970). At certain points on the corallum margins, a thickened wall may be observed (Fig. 12a) on which a number of trabeculae looking like a holacanth develop, forming spines.

The median dark line has an average thickness of 30 to $35 \mu \mathrm{m}$. and consists of isodiametric or transversally stretched 


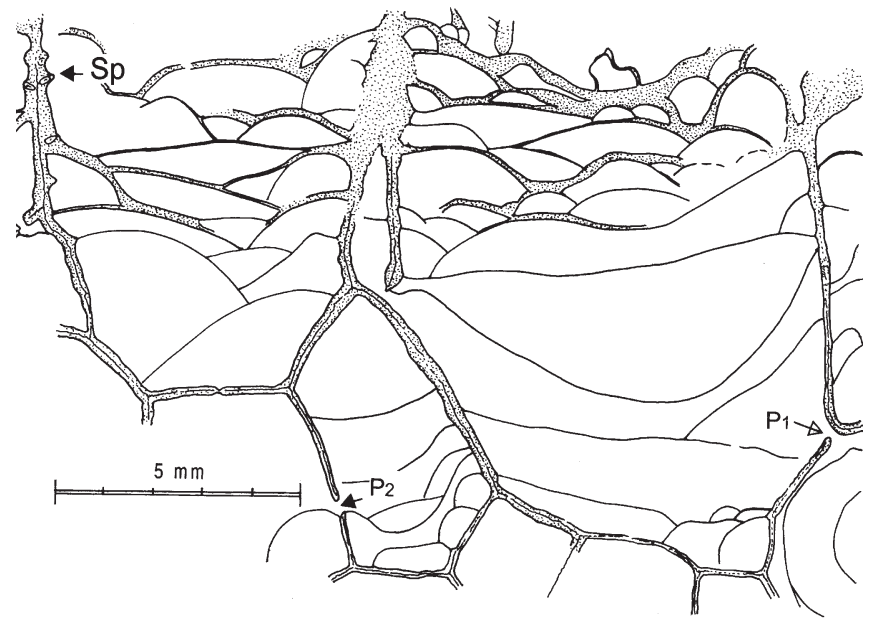

Figure 8. Praemichelinia steli n. sp, DPO 15446, holotype; acetate peel. Detail of the peripheral region of the corallum, longitudinal section at a slight angle. Sp: trabecular spine; $\mathrm{P}_{1}$ : corner pore; $\mathrm{P}_{2}$ face mural pore.
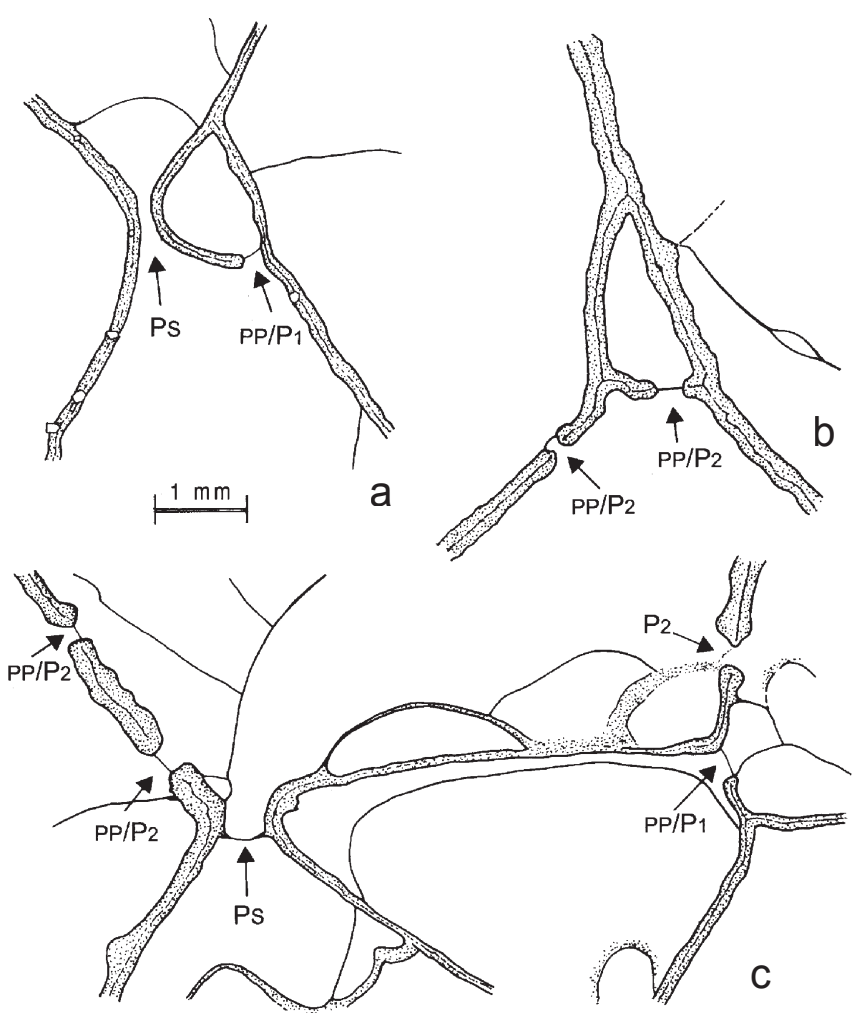

Figure 9. Praemichelinia steli $\mathrm{n}$. sp. The appearance of different types of pores in cross-section. a, DPO 15448, paratype; acetate peel. Ps: solenia-like pore; $\mathrm{pp} / \mathrm{P}_{1}$ : corner pore with a pore-plate. b, DPO 15446, holotype; thin section B 46808, face mural pores (with pore-plate); their lateral position on the side of the corallite should be noted. c, DPO 15447, paratype; acetate peel. Ps: solenia-like pore; the associated structure would appear to be a tabula or a tabella rather than a pore-plate. The presence of two $\mathrm{P}_{2}$ pores on the same wall to the left should be noted. granulae whose average diameter is around 8.05 by $4.7 \mu \mathrm{m}$. (Fig. 13).

Throughout the corallum, longitudinal sections show the sclerenchyma composed of lamellae set at an angle with distal divergence. The angle between the lamella and the median dark line is approximately $20^{\circ}$ to $25^{\circ}$ (Figs. 12, 13).

Morphologically, lamellae are flat, somewhat undulating or slightly curved, with the concavity towards the axis of the corallite. They present a totally irregular outline which is conditioned by the presence of cupular elements. These domes are less clear-cut than those observed in microlamellar elements (this is a generalized phenomenon). However, in general their concavity faces towards the lumen and hence their polarity indicates the direction of growth of the skeleton (Fig. 13).

As is often the case, between the median dark line and the typical lamellae a zone appears where the morphology of elements is not sharply defined, with irregular shapes or thickened and curving microstructural elements (cf. Saouraepora armoricana Plusquellec, Tourneur \& Lafuste, 1993: fig. 31; herein Fig. 13).

Mean diameters ("length" and "thickness") of the lamellae are respectively 34.6 and $4.01 \mu \mathrm{m}$, as shown in Fig. 14.

Remarks on tabulae and tabellae: As the description suggests, the morphology and arrangement of tabulae and tabellae in longitudinal sections do not allow a clear distinction to be made on these bases between axial and peripheral regions, or between proximal and distal zones, in the lumina of the samples studied. However, when the vertical development of the coralla is considered, crosswise elements show a more or less horizontal pattern of cyclomorphic origin, so each morphological region records, even if not in a clear way, a distinct and specific moment during the growth of coralla.

Remarks on Solenia-like pores: From a structural and microstructural point of view and in cross section, solenialike pores are distinguished by the following features: 1) one side, shared by two adjacent corallites, is completely

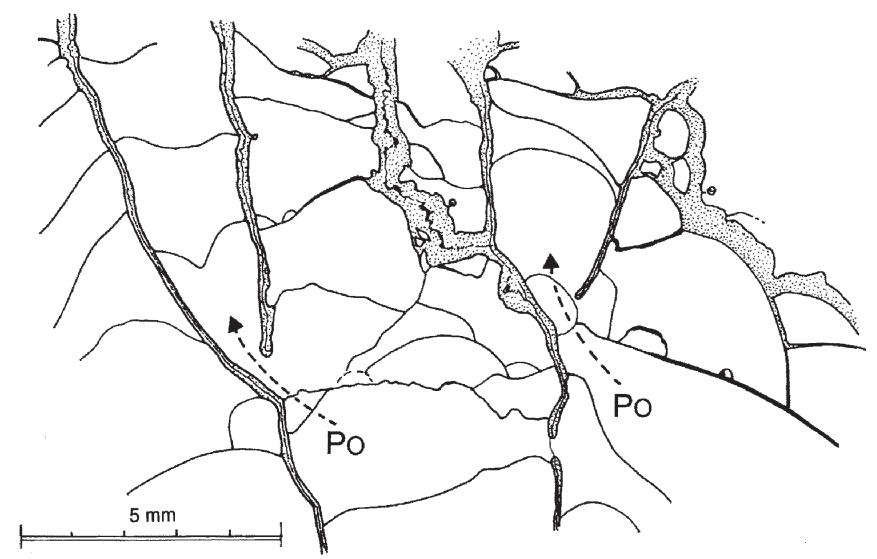

Figure 10. Praemichelinia steli n. sp. DPO 15447, paratype; acetate peel. The figure shows a lateral growth at the edge of the colony. $\mathrm{P}_{\mathrm{O}}$ : basal pore. 


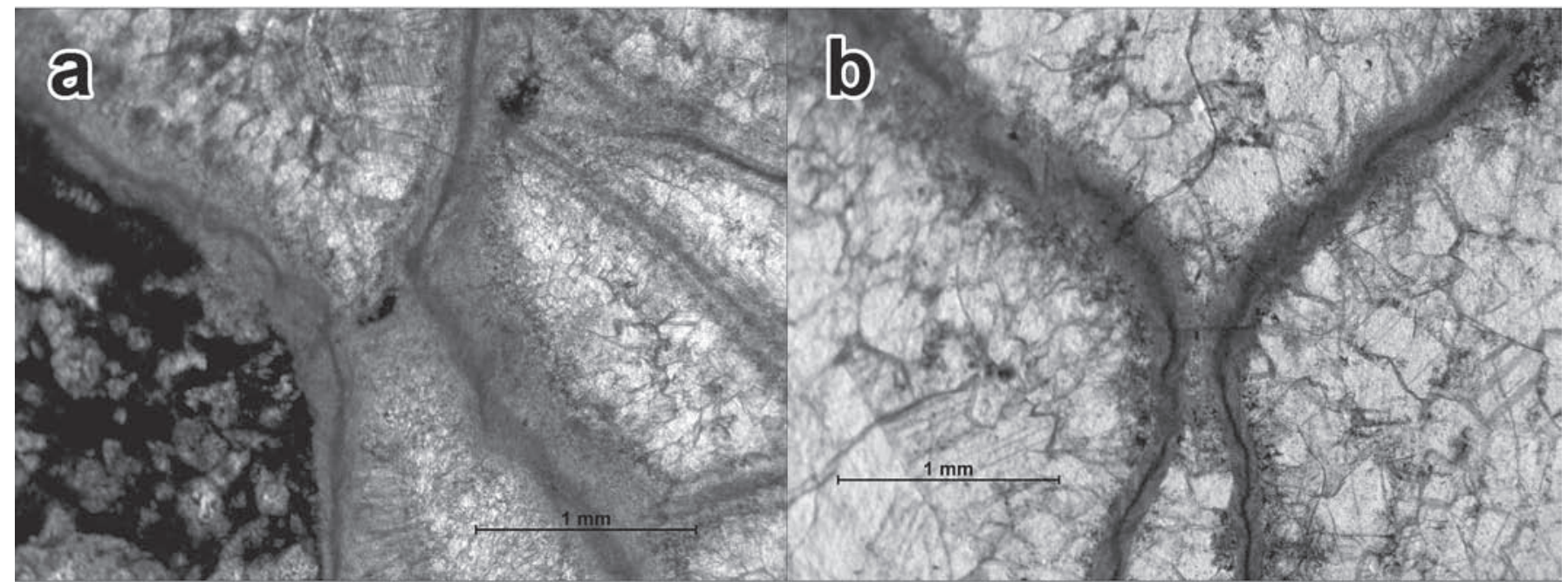

Figure 11. Praemichelinia steli n. sp., morphology of the solenia-like pores. a, DPO 15446, holotype; thin section. b, DPO 15448, paratype; thin section.

replaced by a pore; and 2) on both sides of the solenialike pore, the wall describes a continuous, regular, convex curve, which also occurs at the median dark line. This pattern is totally comparable with what is observed at one, and only one, side of $\mathrm{P}_{1}$ pores, specifically the side lying in the angle of the corallite (Fig. 15).

This is in agreement with Stel \& Oekentorp (1976) who state: "in our opinion solenia are not functionally and genetically different from pores as Sokolov (1951) maintains". Nevertheless, owing to the features mentioned above, it is not possible to accept an equivalence between corner pores $\left(\mathrm{P}_{1}=\right.$ corner pores $=$ eckständige Poren $)$ and solenia-like pores, as proposed by Stel \& Oekentorp (1976) and by Oekentorp (1976). In fact, in addition to connective pores, three different kinds of mural pore, corresponding to three different structures, need to be distinguished in Tabulate Corals: corner pores $\left(\mathrm{P}_{1}\right)$, solenia-like pores (Ps) and face mural pores $\left(\mathrm{P}_{2}\right)$ (Fig. 15).

In the current state of knowledge, pores of the solenialike type have been described only in Silurian Favositidae. In Micheliniidae, such structures had escaped notice, doubtless because of their rarity, but it is highly likely that systematic searching would allow them to be identified in other species.

On these lines, a brief overview of a range of material has permitted confirmation of the occurrence of a few scarce solenia-like pores in:

- A specimen of Praemichelinia sp. Aragón in Spain, Lower Pragian.

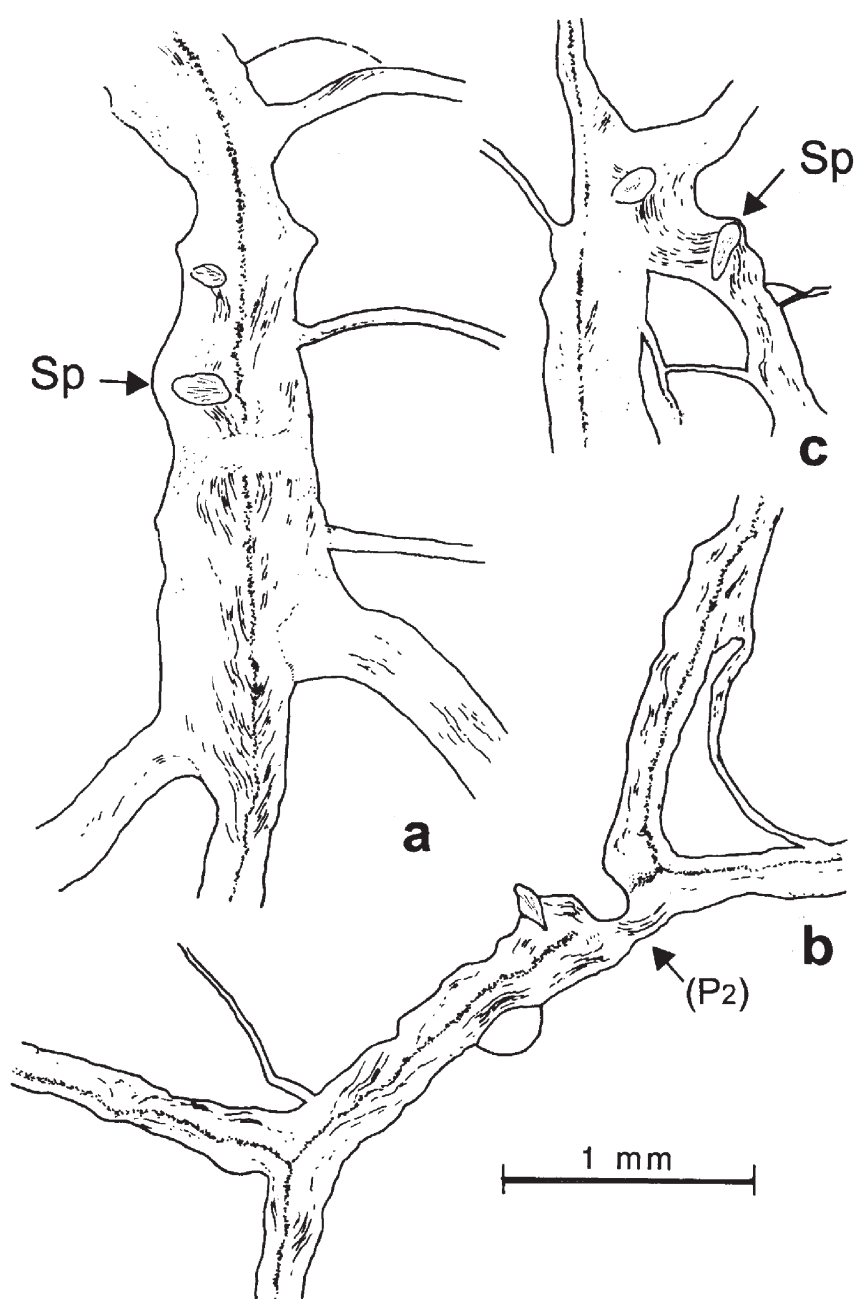

Figure 12. Praemichelinia steli n. sp. Microstructure under low-power magnification. a-b, DPO 15446, holotype; thin section B 46808. a, Longitudinal section of the wall showing the regular divergence of the lamellae and the presence of trabecular spines (Sp). b, Cross-section showing the variable positioning of the lamellae in relation to the median suture. c, DPO 15447, paratype; peel, longitudinal section showing, to the right, a thick tabella bearing spines ( $\mathrm{Sp}$ ) (uncommon in this species). 


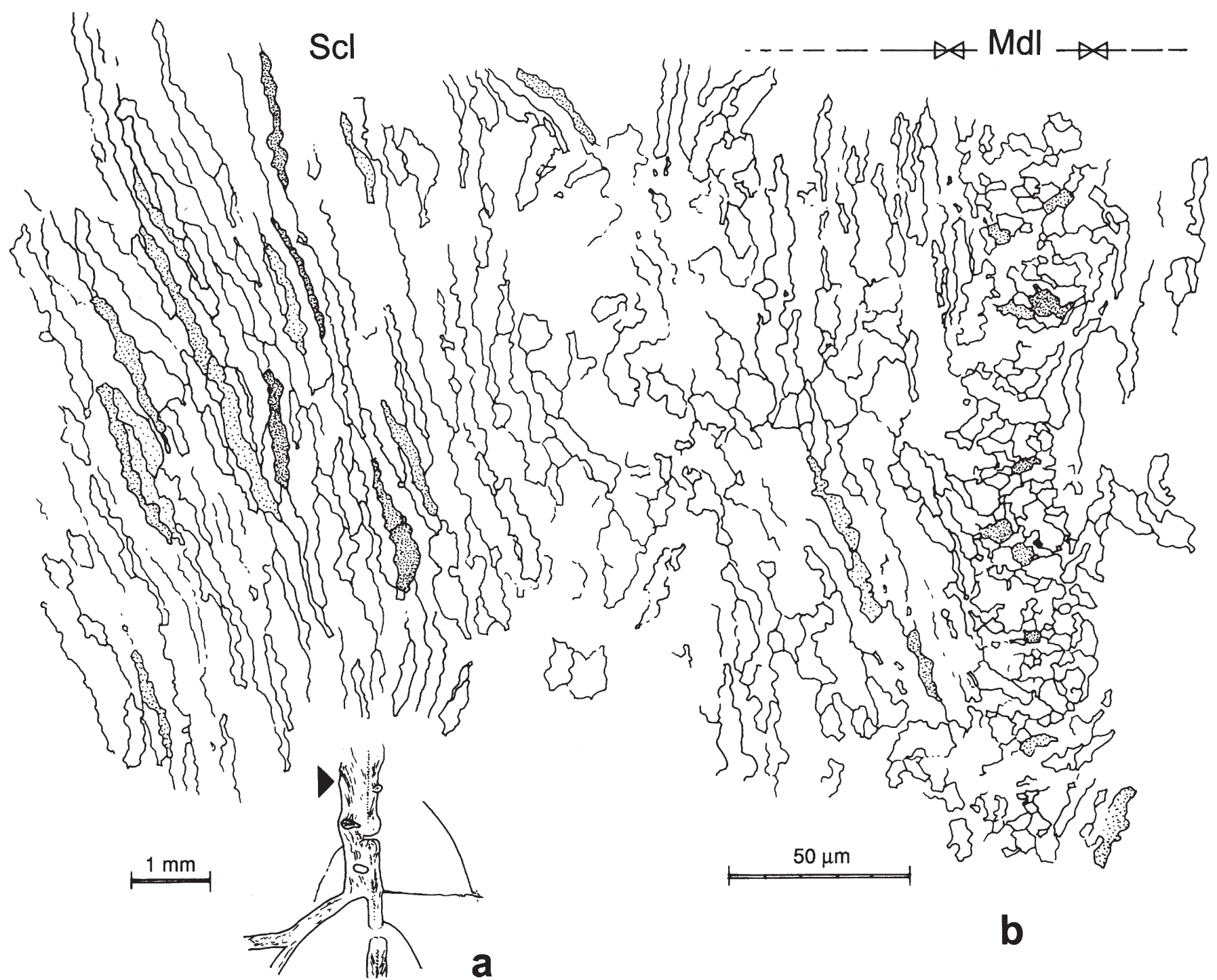

Figure 13. Praemichelinia steli n. sp. Microstructure greatly magnified. DPO 15448, paratype; thin section LFP B 46840. a, Longitudinal section showing the position of the region figured in detail in $\mathbf{b}$. b. From right to left: granular median dark line (Mdl) and divergent lamellae of the parietal sclerenchyma ( $\mathrm{Scl})$.

- A sample of Praemichelinia sp. Saint-Céneré Formation, Saint-Céneré Section, at Saint Céneré in Mayenne (France). Level Sc 42-43, Upper Lochkovian, thin section LPB 2416, figured in Plusquellec (1976: fig. 42, central part of the section, to the left of a $\mathrm{P}_{2}$ pore).

- P. guerangeri guerangeri L'Armorique Formation, Pointe de l'Armorique Section in the Rade de Brest, Finistère (France). Level N87, Pragian, thin section LPB 4267a, recorded by Lafuste \& Plusquellec (1980)

- P. guerangericryptospinosa, L'Armorique Formation, in the cliff of La Fraternité Section at Roscanvel in the Crozon Peninsula,Finistère (France). UpperLochkovian, thin section LPB 4265a, noted by Lafuste \& Plusquellec (1980)

- Praemichelinia sp. Lower part of the La Vid Group, Vegacervera Section, on the southern slope of the Cantabrian Mountains (Spain). Precise provenance unknown. Lochkovian-?Emsian.
The questions arise of what systematic and phylogenetic value should be attached to the chance occurrence of solenia-like pores in Praemichelinia and whether this occurrence demonstrates any remote relationship with Palaeofavositidae. At present there is an insufficient quantity of data to answer these questions. However, the occurrence of numerous corner pores $\left(\mathrm{P}_{1}\right)$ in both the Palaeofavositidae and the Micheliniidae families suggests that the development of solenia-like pores cannot be simply coincidence.

\section{DISCUSSION}

The main problem related to the study of Micheliniidae at a specific level arises from the incomplete knowledge of the majority of the species of Micheliniidae that have been described. For many of them the microstructure is 


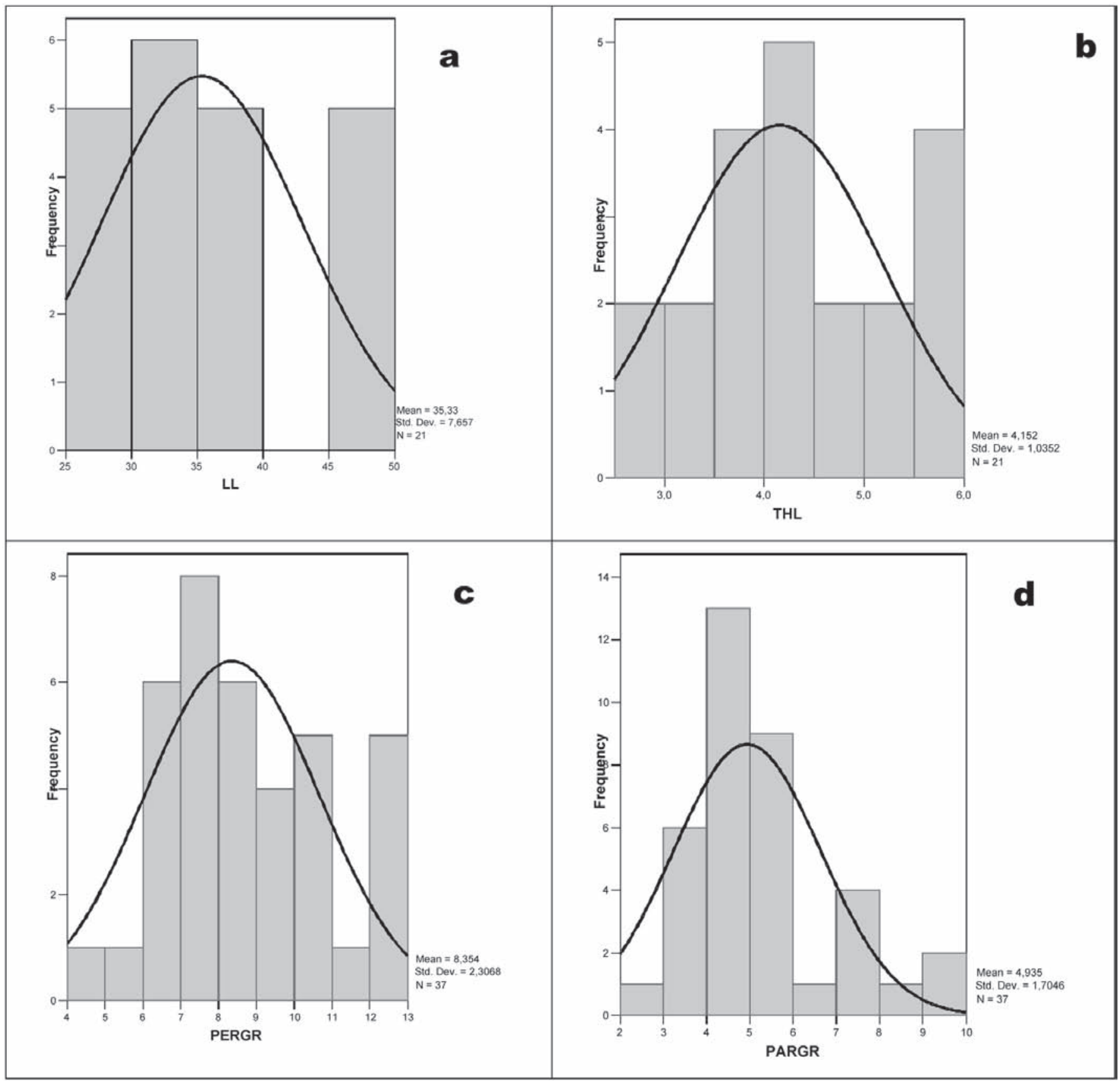

Figure 14. Praemichelinia steli $n$. sp. Frequency distribution for the dimensions of microstructural elements. a, Lamellae, longer dimension or "length" (LL). b, Lamellae, shorter dimension or "thickness" (THL). c-d, Dimensions of the granulae (PERGR, perpendicular to the mural axis and PARGR, parallel to the axis of the wall).

unknown and it would hence not seem possible at present to achieve generic determination for them.

Among the Devonian species accepted as Praemichelinia, only those with a large corallite diameter are comparable with the Colle material. These comprise the following (Table 1):

Praemichelinia sp. Specimen EM 15611, in the collection of the École des Mines housed in the Centre Commun des Collections de Géologie, Université Claude Bernard, Lyon 1 in Villeurbanne, $c f$. Lafuste \& Plusquellec (1988:
184-185), not illustrated in the paper quoted but shown here (Fig. 16). Shale and limestone of the Néhou Formation, Néhou, in the NE of the Central-North Armorican Domain, possibly on the boundary between Lower Lochkovian and Upper Lochkovian. This specimen has main corallites with 10 or more sides, whose diameter is approximately between 8 and $9 \mathrm{~mm}$ (7.90 to $9.02 \mathrm{~mm}$ ), slightly smaller than the size of the Colle material. It differs from Colle material in the occurrence of a region that stands out by reason of the extensive occurrence of small vesicles 

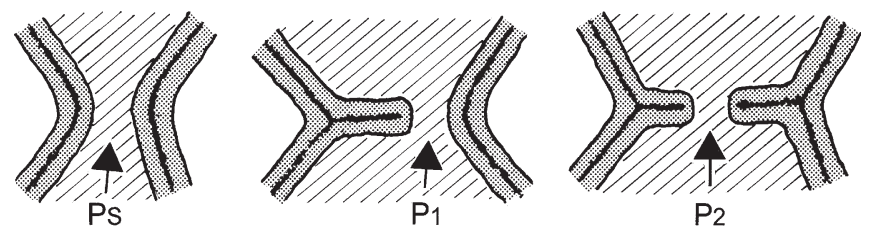

Figure 15. Sketch of the general morphology and structure of the three kinds of pores in transverse section. Ps: solenia-like pore; $\mathrm{P}_{1}$ : corner pore; $\mathrm{P}_{2}$ : face mural pore (here, a midface mural pore).

(Fig.16). On either side of this zone, the disposition and density of tabulae and tabellae are quite similar to those observed in P. steli. However, the considerable difference in age between these materials demands circumspection in establishing any relationships between them, especially because of the scarcity of the material: a single specimen whose calicinal morphology is unknown

Praemichelinia sp. or n. sp. (Plusquellec, unpublished) Nogueras Formation, Los Carniceros locality to the north of Santa Cruz, in Aragón, Spain, level d2cß, Lower Pragian. This species shows main corallites with 8 to 10 sides, whose diameter is between 6.5 and $7 \mathrm{~mm}$. It differs from P. steli in the corallite diameter, which is appreciably smaller than the diameter of the Colle material. It differs also in having a different organization pattern of transverse elements, since the complete, concave tabulae are not laid out in sets as it happens in $P$. steli, even if not universally.

Praemichelinia transitoria (Knod, 1908), Icla Formation (lower part), Chuquisaca province, Bolivia, probably upper Pragian. An illustration of this material can be seen in Plusquellec (1987: figs. 1-4). The diameter of the main corallites, with 10 sides, reaches 8.5 to $10 \mathrm{~mm}$, very close to the corallite size of the Colle material. Moreover, P.transitoria shows sets of concave tabulae (Plusquellec, 1987: fig. 1 lower left) which are also reported in P. steli. Nevertheless, the peripheral part of the corallum in P. transitoria consists of fewer vesicles than in $P$. steli. In addition, $P$. transitoria shows a somewhat unusual microstructure, distinguished by the occurrence of fibrous thickenings on tabulae and walls (Plusquellec, 1987: fig.4).
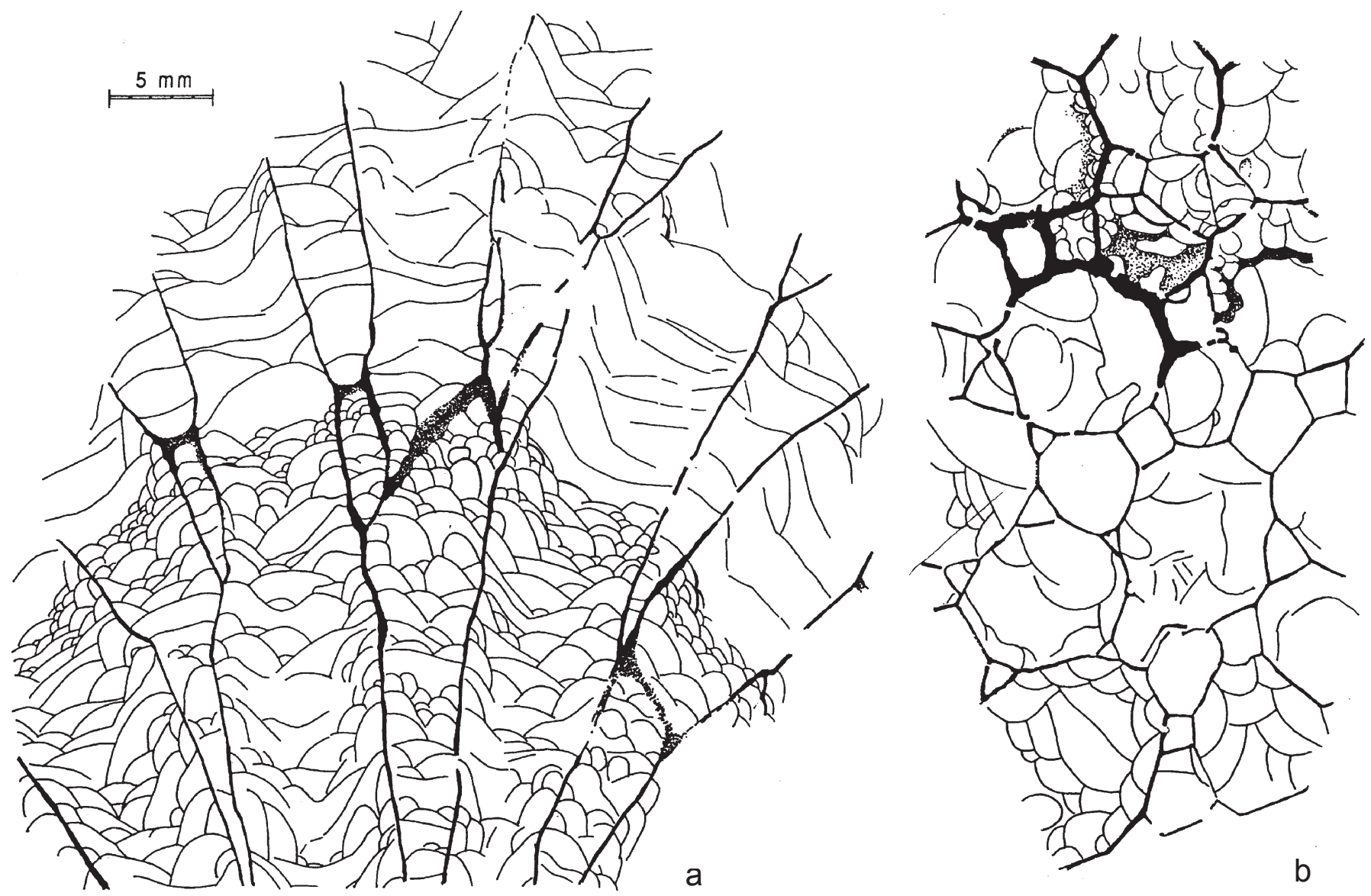

Figure 16. Praemichelinia sp. Acetate peel LPB 9894/EM 15611, from the collection of the École des Mines, Lyon, $c f$. Lafuste \& Plusquellec (1988), Néhou (Lochkovian), NE Armorican Massif. a, Longitudinal section. b, Transverse section on the boundary between two regions with different growth rates; note the presence of a region characterized by the intense development of small vesicles. 


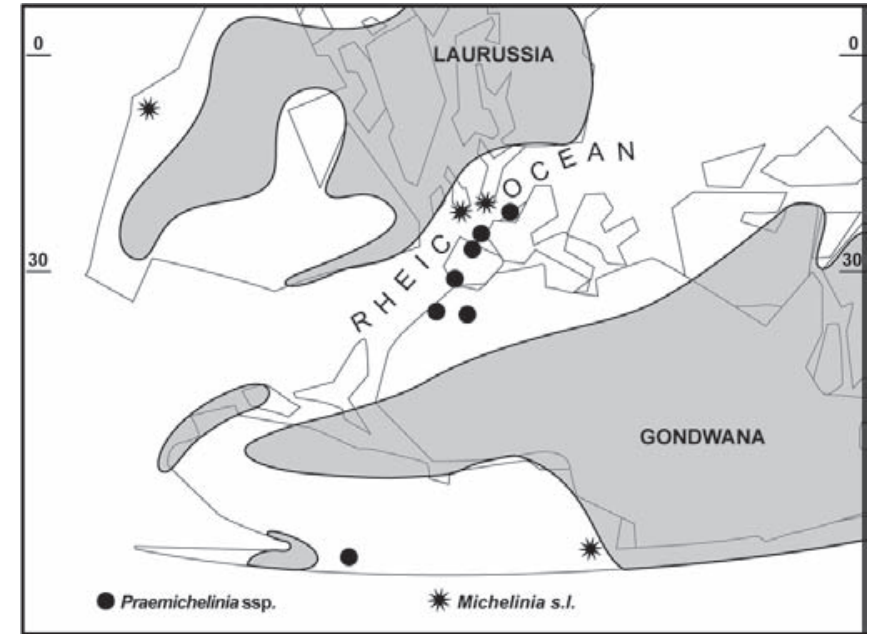

Figure 17. Palaeogeographic sketch for the Emsian (after Scotesse \& McKerrow, 1990; Giessen-Harz nappes have been combined with Gondwana), showing the distribution of Praemichelinia and Michelinia sensu lato (equating to Praemichelinia and/or Michelinia sensu stricto). The occurrence of these taxa in Southern America should be noted.

Regarding to $P$. transitoria, it is appropriate to point out that this comparison is based on no more than three specimens from Colle and two coralla from South America. In addition, in the Bolivian material only the lectotype has thin sections. The comparison of the calicinal morphology is quite tricky because of the currently limited knowledge of P. steli. While the wall of $P$. steli seems to be smooth, the wall of $P$. transitoria comprises 5 or 6 long flattened ridges, which are located along the corallite sides, close to small pores. On one side of a single corallite, as many as 5 horizontally aligned pores have been reported. Paradoxically, pores at sections of the corallum are very scarce and only a few rare wall pores $\left(\mathrm{P}_{2}\right)$ have been observed.

Praemichelinia convexa (d'Orbigny, 1847), sensu Le Maître, 1952, Chefar el Ahmar Formation, "coral-bearing level", Ougarta, Algeria, Upper Emsian. This species was illustrated by Le Maître (1952: Plate XIII figs. 1-7). It shows very large main corallites, whose diameter can reach $12 \mathrm{~mm}$, and strong development of vesicular tabellae with only a few scarce complete tabulae.The species assigned to Michelinia s.s. distinguished by walls composed of parallel lamellae can be left out of this discussion, even if they show large corallites, as does the true M. convexa d'Orbigny 1850, Onondaga Limestone, Virginia, USA, Lower Eifelian.

Finally, just for information, it is possible to quote "Michelinia" cf. rossica Semenow \& Möller in Reed, 1922, from the Middle Devonian of Pamir. This is a very poorly known species, which lacks a precise genus attribution. The corallite diameter is indicated as 8 to $10 \mathrm{~mm}$.
In conclusion, the Colle material can be proposed as a new species, characterized by sharing some features with $P$. transitoria. For the moment, it is not possible to evaluate the degree of relationship between these two periGondwanic micheliniids.

\section{PALAEOBIOGEOGRAPHY (EARLY DEVONIAN)}

In the present state of knowledge, the genus Praemichelinia, identified primarily by microstructural and secondarily by structural features, has been reported in two domains of Gondwana for periods from the early-late Lochkovian to the latest Emsian. In the Ibarmaghian Domain, it has been reported in Northern Africa (Ougarta, Maïder), in Spain (Iberian Chains, Ossa-Morena Zone) and in France (Armorican Massif). In the western region of Gondwana, Praemichelinia has been reported in the Malvinokaffric Realm (Bolivia).

The occurrence of this genus in Kellerwald, pointed out by Plusquellec \& Jahnke (1999) requires some comment. Kellerwald belongs to the Giessen-Harz Nappe Domain and, if various items of palaeontological and sedimentological data are taken into account, this Domain seems highly likely to have originated in northern Gondwana. Hence, Praemichelinia would not have been reported to the north of the Rheic Ocean.

In addition, there is the genus Saouraepora, considered as "une forme branchue du groupe Praemichelinia" (a branched form of Praemichelinia group) which was found in the Ibarmaghian Domain, part of the northern edge of Gondwana, by Plusquellec et al. (1993).

During the Early Devonian, the genus Michelinia s.s. (or at least a genus close to Michelinia) is known only in Algeria and Australia. In spite of the quite different morphologies in the two cases mentioned, the species have been assigned to the genus Holacanthopora Le Maître, 1954, which does not seem to be distinguishable from Michelinia s.s, according to Lafuste \& Plusquellec (1985). The species in question are Holacanthopora fascialis (Le Maître, 1952), probably from the "coral-bearing level" at Chefar el Ahmar Formation at Ougarta in Algeria, dating from the latest Emsian and Holacanthopora clarkei Wright \& Flory (1979/1980), Mount Frome Limestone Formation, Upper Emsian (probably middle Dalejian), Lachlan Fold Belt, in New South Wales in Australia.

Therefore, at the present state of knowledge, Michelinia s.s. has been not identified prior to the upper Emsian. Later, this genus was found on the edges of Laurussia. This is Michelinia convexa d'Orbigny, 1850, from the early Eifelian of the Appalachian Basin (see Lafuste \& Plusquellec, 1985).

In addition, during the early Devonian, some Michelinia in the broadest sense, that is to say, coralla with unknown 


\begin{tabular}{|c|c|c|c|c|}
\hline Species & Locality & Formation & Stage & Publication \\
\hline $\begin{array}{l}\text { Praemichelinia } \mathrm{n} . \mathrm{sp} . \text { ? e.g. guerangeri } \\
\text { guerangeri (ME \& H 1851) }\end{array}$ & \begin{tabular}{|c|} 
Kellerwald, Giessen- \\
Harz Nappe (Germany)
\end{tabular} & $\begin{array}{l}\text { Ebslochgrauwacke } \\
\text { Formation }\end{array}$ & Lower Emsiam & $\begin{array}{l}\text { Plusquellec \& } \\
\text { Jahnke, } 1999\end{array}$ \\
\hline $\begin{array}{l}\text { Praemichelinia guerangeri } \\
\text { cryptospinosa LAFUSTE \& } \\
\text { PLUSQUELLEC } 1980\end{array}$ & $\begin{array}{c}\text { Armorican Massif, } \\
\text { Western border, middle } \\
\text { Synclinorium (France) }\end{array}$ & $\begin{array}{l}\text { L'Armorique } \\
\text { Formation }\end{array}$ & $\begin{array}{l}\text { boundary Lower/ } \\
\text { Upper } \\
\text { Lochkovian }\end{array}$ & $\begin{array}{c}\text { Lafuste \& } \\
\text { Plusquellec, } 1980\end{array}$ \\
\hline $\begin{array}{l}\text { Praemichelinia } \mathrm{sp} \text {. Described as } \\
\text { «Micheliniidae indet». It looks close to } \\
\text { P. guerangeri cryptospinosa }\end{array}$ & $\begin{array}{c}\text { Armorican Massif, } \\
\text { Eastern border, middle } \\
\text { Synclinorium (France) }\end{array}$ & $\begin{array}{l}\text { Saint Céneré } \\
\text { Formation }\end{array}$ & $\begin{array}{c}\text { Upper } \\
\text { Lochkovian }\end{array}$ & Plusquellec, 1976 \\
\hline $\begin{array}{l}\text { Praemichelinia gerangueri guerangeri } \\
\text { (ME \& H 1851) }\end{array}$ & $\begin{array}{c}\text { Armorican Massif, } \\
\text { Western border, middle } \\
\text { Synclinorium (France) } \\
\end{array}$ & $\begin{array}{l}\text { L'Armorique } \\
\text { Formation }\end{array}$ & $\begin{array}{c}\text { Upper } \\
\text { Lochkovian-Pragian }\end{array}$ & $\begin{array}{c}\text { Lafuste \& } \\
\text { Plusquellec, } 1980\end{array}$ \\
\hline $\begin{array}{l}\text { Praemichelinia gerangueri guerangeri } \\
\text { (ME \& H 1951) }\end{array}$ & $\begin{array}{c}\text { Armorican Massif, } \\
\text { Eastern border, middle } \\
\text { Synclinorium (France) }\end{array}$ & $\begin{array}{l}\text { Saint Céneré } \\
\text { Formation }\end{array}$ & $\begin{array}{l}\text { Probably } \\
\text { Pragian }\end{array}$ & $\begin{array}{c}\text { Lafuste \& } \\
\text { Plusquellec, } 1980\end{array}$ \\
\hline Praemichelinia sp. & $\begin{array}{c}\text { Armorican Massif, } \\
\text { Northern area (France) }\end{array}$ & Néhou Formation & Lochkovian & $\begin{array}{c}\text { Lafuste \& } \\
\text { Plusquellec, } 1988\end{array}$ \\
\hline Praemichelinia sp. & $\begin{array}{l}\text { Iberian Mountains } \\
\text { Aragón (Spain) }\end{array}$ & $\begin{array}{l}\text { Nogueras Fm. } \\
\text { d2c } \beta\end{array}$ & Lower Pragian & $\begin{array}{l}\text { Plusquellec } \\
\text { unpublished }\end{array}$ \\
\hline Praemichelinia sp. & $\begin{array}{l}\text { Iberian Mountains } \\
\text { Aragón (Spain) }\end{array}$ & $\begin{array}{l}\text { Mariposas Fm. } \\
\text { d4ay }\end{array}$ & Lower Emsiam & $\begin{array}{l}\text { Plusquellec } \\
\text { unpublished }\end{array}$ \\
\hline $\begin{array}{l}\text { Praemichelinia homofavosa } \\
\text { (LE MAÎTRE 1952), described as } \\
\text { "Michelinia" homofavosa }\end{array}$ & $\begin{array}{l}\text { Ossa Morena Zone } \\
\text { Cordoba (Spain) }\end{array}$ & Lorito Limestone & $\begin{array}{c}\text { Upper } \\
\text { Lochkovian }\end{array}$ & Crousilles et al. 1978 \\
\hline $\begin{array}{l}\text { Praemichelinia homofavosa } \\
\text { (LE MAÎTRE 1952) }\end{array}$ & $\begin{array}{l}\text { Ougarta, El Kseib } \\
\text { (Algerie) }\end{array}$ & $\begin{array}{l}\text { Dkhissa Formation } \\
\quad \text { (lower part) }\end{array}$ & $\begin{array}{c}\text { Upper } \\
\text { Lochkovian }\end{array}$ & Plusquellec, 1997 \\
\hline Praemichelinia sp. & $\begin{array}{l}\text { Anti-Atlas, Maïder } \\
\text { (Morocco) }\end{array}$ & Ihandar Formation & Upper Pragian & $\begin{array}{c}\text { Lafuste \& } \\
\text { Plusquellec, } \\
\text { unpublished }\end{array}$ \\
\hline Praemichelinia ssp. & Ougarta, (Algerie) & $\begin{array}{l}\text { Dkhissa Formation } \\
\text { (upper part) \& } \\
\text { Teferguenit Fm. }\end{array}$ & $\begin{array}{l}\text { Pragian-Upper } \\
\text { Emsiam }\end{array}$ & Plusquellec, 1997 \\
\hline $\begin{array}{l}\text { Praemichelinia } \text { sp. = Michelinia } \\
\text { convexa sensu LE MAIITRE, } 1952\end{array}$ & $\begin{array}{l}\text { Ougarta, Marhouma } \\
\text { (Km. 30) (Algerie) }\end{array}$ & $\begin{array}{l}\text { Chefar el Ahmar } \\
\text { Formation }\end{array}$ & Uppermost Emsian & $\begin{array}{c}\text { Lafuste Plusquellec, } \\
1985 \\
\end{array}$ \\
\hline $\begin{array}{l}\text { Praemichelinia transitoria (KNOD } \\
1908)\end{array}$ & Icla (Bolivia) & Icla Formation & Pragian & Plusquellec, 1987 \\
\hline $\begin{array}{l}\text { Michelinia s.l. } \\
* \text { Microstructure totally recristallized. }\end{array}$ & $\begin{array}{l}\text { Ardenas } \\
\text { (Belgium) }\end{array}$ & Villé Formation & Pragian & $\begin{array}{l}\text { Plusquellec } \\
\& \text { Tourneur } \\
\text { unpublished }\end{array}$ \\
\hline $\begin{array}{l}\text { Michelinia s.l. cited as } \\
\text { Michelinia cf. M. auloporoides } \\
\text { LE MAÎTRE } 1952 * \text { In fossil list }\end{array}$ & $\begin{array}{l}\text { Central Nevada } \\
\text { (USA) }\end{array}$ & $\begin{array}{l}\text { Rabbit Hill } \\
\text { Limestone }\end{array}$ & Pragian & Flory, 1977 \\
\hline $\begin{array}{l}\text { Michelinia? } \\
* \text { In fossil list }\end{array}$ & $\begin{array}{c}\text { Central Nevada } \\
\text { (USA) }\end{array}$ & $\begin{array}{l}\text { Rabbit Hill } \\
\text { Limestone }\end{array}$ & Pragian & Flory, 1977 \\
\hline $\begin{array}{l}\text { Michelinia s.l. identified as } \\
\text { Protomichelinia sp. } \\
\text { * Recristallized and deformed }\end{array}$ & $\begin{array}{l}\text { Crabrock Point } \\
\text { Brixham, Devon } \\
\text { (Great Britain) }\end{array}$ & $?$ & Pragian-Emsiam & \begin{tabular}{|l} 
D.E. White, \\
unpublished, in coll. \\
Seen by Y.P. \\
\end{tabular} \\
\hline $\begin{array}{l}\text { Michelinia s.l. as } \\
\text { Michelinia } \mathrm{sp.} \\
\text { * In fossil list }\end{array}$ & Parana (Brazil) & $?$ & ?Emsiam & $\begin{array}{c}\text { Mendes \& Petri, } \\
1971\end{array}$ \\
\hline
\end{tabular}

Table 1. Reports of Praemichelinia and Michelinia sensu lato (equating to Praemichelinia and/or Michelinia, sensu stricto) in the Lower Devonian. 
microstructural features because of poor preservation or incomplete data, have been reported from a range of places. These specimens belong either to the genus Praemichelinia or to Michelinia s.s., because the genus Turnacipora (microlamellar "Michelinia") has only been reported during the Carboniferous. Figure 17 and table 1 provide data on the Micheliniidae family during the early Devonian.

In conclusion, taking into account the data available at present, Micheliniidae with divergent lamellae (Praemichelinia, Saouraepora) originated in northern Gondwana, where they remained during the early Devonian. The occurrence of the genus Praemichelinia in the Cantabrian Zone adds a new element to this panorama.

\section{ACKNOWLEDGEMENTS}

We are grateful to L.P. Fernández of the University of Oviedo (Spain) for providing the stratigraphical level in figure 3 and some sedimentological data from Colle. Antonio Buil Romero drew figures 1,2, 3 and 17. Thanks are due to the two paper reviewers, Dr. Francisco Soto and Dr. Sergio Rodriguez, whose observations have greatly improved the text. This study is a component part of projects BTE 2003-02065, IGPC 499 and IGPC 471 and a contribution to the research project CGL 2005-03715/ BTE financed by the "Dirección General de Investigación" of the Spanish Ministry of Education and Science and FEDER (The European Regional Development Fund).

\section{REFERENCES}

Alonso, J.L. 1989. Síntesis cartográfica de la región del manto del Esla. Trabajos de Geología, 18, 155-163.

Crousilles, M., Dixsaut, C. \& Lafuste, J. 1978. Données nouvelles sur les calcaires du Dévonien inférieur de la Province de Cordoue (Espagne). Comptes rendus de l'Académie des Sciences de Paris, 286D, 507-509.

Fernández, L.P., Nose, M., Fernández-Martínez, E., Méndez-Bedia, I., Schröder, S. \& Soto. F. (in press). Reefal facies development in the Lower Devonian La Vid Group (Cantabrian Zone, NW Spain). Facies.

Flory, R.A. 1977. Devonian Tabulate Corals of Central Nevada. University of California, Riverside Campus Museum Contributions, 4, 89-98.

García-Alcalde, J.L. 1997. North Gondwanan Emsian Events. Episodes, 20, 241-246.

García-López, S. \& Sanz-López, J. 2002. Devonian to Lower Carboniferous Conodont Biostratigraphy of the Bernesga Valley Section (Cantabrian Zone, NW Spain). In: Paleozoic Conodonts from Northern Spain (Eds. S. García-López \& F. Bastida). Instituto Geológico y Minero de España, Cuadernos del Museo Geominero series, 1, Madrid, 163-205.

Keller, M. \& Grötsch, J. 1990. Depositional History and Conodont Biostratigraphy of the Lower Devonian La Vid Group in the Luna Area (Cantabrian Mountains, NW
Spain). Neues Jarhbuch für Geologie und Paläontologie, 1990, 141-164.

Lafuste, J. 1970. Lames ultra-minces à faces polies. Procédé et application à la microstructure des madréporaires fossiles. Comptes rendus de l'Académie des Sciences de Paris, 270D, 679-681.

Lafuste, J. \& Plusquellec, Y. 1980. Les polypiers Tabulata. In: Les Schistes et calcaires de l'Armorique (Dévonien inférieur du Massif Armoricain) (Ed. Y. Plusquellec). Mémoires de la Société géologique et minéralogique de Bretagne, 23, 143-173.

Lafuste, J. \& Plusquellec, Y. 1985. Structure et microstructure de quelques michelinidae et michelinimorphes (Tabulata paléozoïques). Bulletin du Musée National d'Histoire Naturelle de Paris, $4^{\mathrm{ème}}$ série, 7, 13-63.

Lafuste, J. \& Plusquellec, Y. 1988. Révision des beaumontia décrits par Milne-Edwards et Haime (Tabulata; Dévonien, Carbonifère). Bulletin du Musée National d'Histoire Naturelle de Paris, $4^{\text {ème }}$ série, 10, 179-197.

Le Maître, D. 1952. La faune du dévonien inférieur et moyen de la Saoura et des abords de l'Erg El Djemel. Matériaux pour la Carte Géologique de l'Algérie. $1^{\text {ère }}$ série, Paléontologie, 12, 1-170.

Mendes, J. \& Petri, S. 1971. Geologia do Brazil. Enciclopédia Brasileira. Instituto Nacional do Livro, Rio de Janeiro, 1-197.

Nothdurf, L. \& Webb, G.E. (in press). "Shingle” Microstructure in Scleractinian Corals: A Possible Analogue for Lamellar and Microlamellar Microstructure in Palaeozoic Tabulate Corals. Proceedings of the $9^{\text {th }}$ International Symposium on Fossil Cnidaria and Porifera; Schriftenreihe der Erdwissenschaftlichen Kommissionen der Österreichischen Akademie der Wissenschaften. Vienna.

Oenkentorp, K. 1976. Revision und Typisierung des Genus Paleofavosites Twenhofel, 1914. Palaeontologische Zeitschrift, 50, 151-189.

Oekentorp, K. \& Schröder, S. 2001. Korallen (Rugosa; Tabulata) aus dem Paläozoikum des SW Sultan Dag, Türkei. In: Contributions to Geology and Paleontology of Gondwana in Honour of Helmut Wopfner. Editorial Cologne, 369-381.

Plusquellec Y. 1976. Les polypiers - Tabulata. In: Les Schistes et calcaires éodévoniens de Saint-Céneré (Massif Armoricain, France) Sédimentologie, paléontologie, stratigraphie (Ed. H. Lardeux). Mémoires de la Société Géologique et Minéralogique de Bretagne, 19, 183-215.

Plusquellec, Y. 1987. Révision de Michelinia transitoria KNOD, 1908 (Tabulata, dévonien de Bolivie). Annales de la Societé Géologique du Nord, 105, 249-252.

Plusquellec, Y. 1997. Coraux Tabulata et Rugosa. In: Les faunes du Dévonien de l'Ougarta (Sahara occidental, Algérie) II (Eds. K. Boumendjel et al.) Annales de la Societé Géologique du Nord, 2ème ser., 5 89-116.

Plusquellec, Y. \& Jahnke, H. 1999. Les tabulés de l'Erbslochgrauwacke (Emsien inférieur du Kellerwald) et le problème des affinités paleogéographiques de l'allochtone «Giessen-Harz». Abhandlungen der Geologischen Bundesanstalt, A, Band 54, 435-451. 
Plusquellec, Y., Tourneur, F. \& Lafuste, J. 1993. Saouraepora nouveau genre de Micheliniidae (Tabulata) du Dévonien du nord de Gondwana et du Carbonifère d'Amérique du nord. Palaeontographica A, 227, 1-86.

Scotese, C.R. \& McKerrow, W.S. 1990. Revised world maps and introduction. In: Palaeozoic palaeogeography and biogeography (Eds. W. S. McKerrow \& C. R. Scotese). Geological Society, London, Memoir, 12, 1-21.

Sokolov, B.S. 1951. Tabuljaty paleozoja evropejskoj chasti SSR. II. Silur Pribaltiki (Favozitidy Llandoverskogo jarusa). [Palaeozoic Tabulates of the European Regions of the USSR. II The Silurian in the Baltic (Favositides of the Llandover Stratum)]. Trudy Vnigri, NS 52, 1-124.

Stel, J.H. 1976. The Influence of Hurricanes upon the Quiet Depositional Conditions in the Lower Emsian La Vid Shales of Colle. Leiden Geologischen Mededelingen, 49 , 475-486.
Stel, J.H. \& Oekentorp, K. 1976. On the Solenoid Growth Habit of Paleofavosites. Geologie en Mijnbouw, 55, 163-174.

Tchudinova, I.I. 1997. On the Phylogeny and Systematics of the Micheliniina (Tabulata). Paleontological Journal, 31, 17-21.

Vera de la Puente, C. 1989. Revisión litoestratigráfica y correlación de los Grupos Rañeces y La Vid (Devónico inferior de la Cuenca Astur-Leonesa). Trabajos de Geología, 18, 53-65.

Vilas Minondo, L. 1971. El paleozoico inferior y medio de la Cordillera Cantábrica entre los ríos Porma y Bernesga (León). Memorias del Instituto Geológico y Minero de España, 80, 1-169.

Manuscrito recibido: 18 de Septiembre, 2005 Manuscrito aceptado: 26 de Enero, 2006 